\title{
Ceramide Synthase 5
}

National Cancer Institute

\section{Source}

National Cancer Institute. Ceramide Synthase 5. NCI Thesaurus. Code C104127.

Ceramide synthase 5 (392 aa, $\sim 46 \mathrm{kDa}$ ) is encoded by the human CERS5 gene. This protein is involved in apoptosis via the mitochondrial death pathway. 